\title{
前立腺肥大症に対する経尿道的単回高温度療法の治療成績
}

\author{
浜松医科大学泌尿器科教室（主任：藤田公生教授） \\ 栗田 豊 影山 慎二 牛山 知已 \\ 鈴木 和雄 藤田 公生 \\ 東京大学医学部泌尿器科（主任：河邊香月教授） \\ 河邊 香 月
}

\section{TRANSURETHRAL MICROWAVE THERMOTHERAPY FOR BENIGN PROSTATIC HYPERPLASIA: A 1-YEAR FOLLOW-UP STUDY}

Yutaka Kurita, Shinjui Kageyama, Tomomi Ushiyama, Kazuo Suzuki and Kimio Fujita Department of Urology, Hamamatsu University School of Medicine

(Director: Prof. K. Fujita)

Kazuki Kawabe

Department of Urology, The University of Tokyo

(Director: Prof. K. Kawabe)

The authors studied a 1-year effect of transurethral microwave thermotherapy (TUMT) using the PROSTCARE apparatus (Bruker Spectrospin Wissembourg, Frace) on 35 patients with symptomatic benign prostatic hyperplasia $(\mathrm{BPH})$. The device is equipped with a unique noninvasive system "radiometry" for the measurement of the intraprostatic temperature to regulate the microwave emission power and to eliminate classic surface controls. All of the 35 patients received a single thermotherapy session (60 minutes), the average intraprostatic temperature was $43.6 \pm 1.2^{\circ} \mathrm{C}$ (mean $\pm \mathrm{SD}$ ) and the average power output was $43.9 \pm 4.1 \mathrm{Watt}$. The clinical effects were evaluated at 2 months, 6 months and 1 year after TUMT by a specially designed score scale for subjective symptoms and objective findings as compared with the pretreatment score. Assuming that more than a 25\% reduction of the total score indicates "effective", $71.4 \%$, 71.4 , and $48.6 \%$ of the treatments remained effective at 2 months, 6 months, and 1 year after TUMT, respectively.

The maximum prostatic urethral pressure profile decreased from $64.1 \pm 17.1$ to $51.7 \pm 15.6$ $\mathrm{cmH}_{2} \mathrm{O}(\mathrm{p}<0.05)$ at 2 months after TUMT.

The thermotherapy by PROSTCARE is effetive in approximately $50 \%$ of patients at least 1 year and there were no major complications associated with TUMT during the follow up period.

Key words: benign prostatic hyperplasia, thermotherapy, microwave

要旨：Bruker Spectrospin 社製プロストケアを用いて35例の前立腺肥大症症例に経尿道的高温度治療 法 (TUMT) を試み，その 1 年間の効果を検討した．前立腺の加温は $915 \mathrm{MHz}$ のマイクロ波により行わ れ，尿道粘膜は冷却した循環水により保護しながら，前立腺内部を高温に加熱することが出来る．また 本装置はラジオメトリー法により前立腺内温度を非侵襲的に測定を行い, マイクロ波の出力を制御して いる．このため, 直腸内に温度センサーを留置する必要がないのが特徵である. 治療はすべて単回 1 時 間で行った。平均前立腺内温度は $43.6 \pm 1.2^{\circ} \mathrm{C}$ (mean $\pm \mathrm{SD}$ ) で平均出力は $43.9 \pm 4.1 \mathrm{Watt}$ であった. 治 療効果の判定は自覚症状, 他覚的所見をスコア化し, 両者の合計を各々治療後 2 力月, 6 力月および 1 年で治療前と比較検討した。スコア減少率が $25 \%$ 以上のものを有効とすると, 治療後 2 力月, 6 力月, 
1 年目で各々 $71.4 \%, 71.4 \%, 48.6 \%$ の有効性を認めた. 最大前立腺部尿道内圧は治療 2 力月目で $64.1 \pm$ $17.1 \mathrm{cmH}_{2} \mathrm{O}$ から $51.7 \pm 15.6 \mathrm{cmH}_{2} \mathrm{O}$ と有意に減少 $(\mathrm{p}<0.05)$ した. 本療法は重篤な副作用もなく, 約 $50 \%$ の症例に対し，すくなくとも 1 年間効果が持続した。

キーワード：前立腺肥大症, 高温度治療法, マイクロ波

\section{緒 言}

前立腺肥大症に対する治療法として，従来より薬物 療法や手術療法があるが，近年非観血的治療法として 温熱療法の有用性が種々検討されている.今回前立腺 肥大症症例に対し，フランス BRUKER SPECTROSPIN 社製経尿道的前立腺高温度療法装置 “プロストケア”を使用し，その 1 年間の治療効果につ いて検討したので報告する。

\section{対象と方法}

\section{1 : 対象}

対象は1992年12月より1993年 3 月までに浜松医科大 学泌尿器科を受診した前立腺肥大症 35 例である。これ らの症例は尿線細小，頻尿，残尿感，排尿時間延長な どの愁訴があり，触診および超音波診断で前立腺肥大 症と診断され, 排尿量が $150 \mathrm{ml}$ 以上の場合の平均尿流 率が $10 \mathrm{ml} / \mathrm{sec}$ 以下のものとした。

患者の年齢は $51 \sim 87$ 歳 (平均 70.4 歳), 経直腸的超音 波断層像による前立腺容積は $17.9 \sim 72.0 \mathrm{ml}$ (平均 34.6 $\mathrm{ml}$ ), 前立腺部尿道長は3.3 $5.4 \mathrm{~cm}$ （平均 $3.9 \mathrm{~cm}$ ）で あった. 治療は単回で原則として外来通院で行った. 前立腺肥大症以外の排尿困難を来す疾患を有する症 例, 前立腺癌, 前立腺炎などの他の前立腺疾患を有す る症例，活動性の尿路感染症を有する症例，尿閉の症 例, 尿道狭窄の症例, 腎機能異常（血清クレアチニン $2 \mathrm{mg} / \mathrm{dl}$ 以上) を呈する症例，その他重篤な合併症のあ る症例は対象から除外した。前立腺腫瘍マーカー (prostatic specific antigen : PSA) が高值を示した症 例あるいは触診上硬結を触知した症例は，あらかじめ 前立腺生検を施行し, 前立腺癌でないことを確認した。 薬物療法を行っていたものは高温度療法の 4 週間前か ら休薬とした。また治療後 2 力月間は前立腺肥大症治 療薬预よび排尿障害治療薬の併用は行わなかった。

\section{$2:$ 装置}

今回治療に用いた装置はフランス BRUKER SPECTROSPIN 社製プロストケアでその外観を Fig. 1 に示す。重量は2 $30 \mathrm{~kg}$ で220V の電源を要する。前立 腺の加温は $915 \mathrm{MHz}$ のマイクロ波により行われ, 最大 出力は $50 \mathrm{~W}$ (機器としての最大可能出力は $100 \mathrm{~W}$ ) に設 定されている. 経尿道的加熱方式では直径 $6 \mathrm{~mm}(18 \mathrm{Fr})$
Fig. 1 The Prostcare is an integrated unit consisting of a microwave generator, a urethral cooling system and a radiometric temperaturemonitoring system.

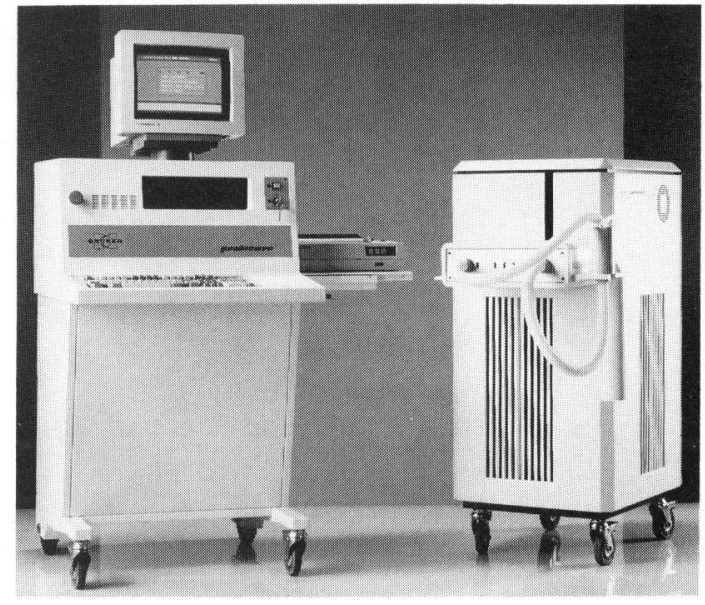

の尿道カテーテルにマイクロ波アンテナと尿道周囲を $20^{\circ} \mathrm{C}$ に冷却するための水循環回路を備えており, 本装 置では尿道粘膜を冷却した循環水により保護し, 前立 腺内部を高温に加熱することが出来る.

前立腺に対する治療温度を測定するために, 本装置 ではラジオメトリーシステムを採用している，治療用 尿道カテーテルに備えられたマイクロ波アンテナが前 立腺に対する加熱機能と前立腺への治療温度測定機能 の両方を備えており，54秒間の加熱の後，次の 6 秒間 で前立腺内の温度をラジオメトリー法により非侵襲的 に測定を行いマイクロ波発信器の出力を制御する. な お, 本機のラジオメトリー法では, 生体組織が熱雑音 として放射するマイクロ波をラジオメーターによって 受診して, 体表からの距離の関数として生体内の温度 分布を算出する。

$3:$ 治療方法

治療は単回 1 時間の加熱とした。 まず，キシロカイ ンゼリーによる尿道粘膜麻酔を施行後, カテーテルを 尿道に挿入, 先端のバルーンに $15 \mathrm{ml}$ の蒸留水を注入し てカテーテルを固定した．次に加熱用アンテナをカ テーテル内に挿入した。アンテナは前立腺部尿道の長 
Table 1 Subjective symptom scoring

\begin{tabular}{l|c|c|c|c}
\hline \multicolumn{1}{c|}{ Score } & 0 & 1 & 2 & 3 \\
\hline $\begin{array}{l}\text { Frequency } \\
\text { (Daytime) }\end{array}$ & $<6$ & $7-10$ & $11-15$ & $\geqq 16$ \\
$\begin{array}{l}\text { Frequency } \\
\text { (Night) }\end{array}$ & 0 & 1 or 2 & 3 or 4 & $\geqq 5$ \\
$\begin{array}{l}\text { Feeling of } \\
\text { Incomplete Voiding }\end{array}$ & None & Occasional & Frequent & Always \\
$\begin{array}{l}\text { Protraction } \\
\text { Retardation }\end{array}$ & None & Mild & Moderate & Severe \\
Urinary Stream & Fone & Mild & Moderate & Severe \\
Forceful & Small & Moderate & Dribbling \\
\hline
\end{tabular}

Table 2 Objective finding scoring

\begin{tabular}{c|c|c}
\hline Score & Residual Urine $(\mathrm{ml})$ & Average Flow Rate $(\mathrm{ml} / \mathrm{s})$ \\
\hline 0 & $0-9$ & $\geqq 15$ \\
1 & $10-29$ & $12-14.9$ \\
2 & $30-49$ & $10-11.9$ \\
3 & $50-99$ & $8-9.9$ \\
4 & $100-149$ & $6-7.9$ \\
5 & $150-199$ & $4-5.9$ \\
6 & $200-299$ & $3-3.9$ \\
7 & $300-399$ & $2-2.9$ \\
8 & $400-499$ & $1-1.9$ \\
9 & $\geqq 500$ & $<1$ \\
\hline
\end{tabular}

さによって，それぞれ長さの違うものを選んだ。

治療後, カテーテルを抜去し, 自排尿を確認した後 に帰宅せしめた．同時に尿路感染予防のため抗生剂の 投与を 1 週間行った。

\section{$4:$ 効果判定}

効果判定のための問診, 検査等は治療終了後 2 力月, 6 力月, 1 年目で行った。

1）自覚症状

Table 1 に従い, 昼間排尿回数, 夜間排尿回数, 排 尿のスタートの遅れ, 排尿時間の延長, 排尿の勢い, 残尿感の 6 項目を $0 \sim 3$ の 4 段階にスコア化し, 治療 前後のスコア合計值を統計学的に比較検討した。

2）他覚所見

Table 2 に従い, 平均尿流率と残尿量について, 各々 を $0 \sim 9$ の10段階にスコア化し, 治療前後で評価した. 両者の合計值につき治療前後で統計学的に比較検討し た. また, 残尿量, 平均尿流率, 最大尿流率について は実測值も検討した。なお，尿流量測定は排尿量 $150 \mathrm{ml}$ 以上の後で行った。また, 治療前, 治療 2 力月後に尿 道内圧測定を施行し最大前立腺部尿道内圧について比 較した. 前立腺生検を施行したものについては, 組織 型を glandular hyperplasia, stromal hyperplasia,
Table 3 Response criteria

\begin{tabular}{c|c}
\hline $\begin{array}{c}\text { Reduction Rate of Total } \\
\text { Score }(\%)^{*}\end{array}$ & Evaluation of Effect \\
\hline$\geqq 50$ & Remarkable \\
$\geqq 25$ & Good \\
$\geqq 10$ & Minor \\
$<10$ & None \\
\hline
\end{tabular}

* (Pre-Post) Pre $\times 100$.

両者の mixed type の 3 型に分け, 治療効果について 比較検討した。

3）有効性

有効性は自覚症状, 他覚的所見の各スコアを合計し, Table 3 に示す判定基準で 4 段階に効果を判定した. まず, (治療前スコア值一治療後スコア值) $\div$ (治療前ス コア值）を算出してスコア減少率 (reduction rate) と した．その減少率が $50 \%$ 以上のもを著効， $50 \%$ 未満 $25 \%$ 以上のものを有効, $25 \%$ 末満 $10 \%$ 以上減少のもの をやや有効, 10\%未満のものを無効とした. また減少 率が $25 \%$ 以上の群を有効群, $25 \%$ 未満の群を無効群と し，両群の背景因子について検討した。

4) 副作用

副作用モニターのため, 治療前後に自覚症状に加え, 血算, 血液生化学, 前立腺腫瘍マーカー即ち, prostatic acid phosphatase (PAP), $\gamma$-seminoprotein $(\boldsymbol{\gamma}$-Sm), prostate specific antigen（PSA）の測定および尿検査 を行った。

5）本治験は GCP（good clinical practice）の規定 に従い, 十分な説明に基づき，文書による同意を得て から行った。またこの治験計画全体も, 浜松医科大学 の治験審查委員会の承認を得てから行った.

6) 統計学的処理

すべての值は mean \pm S.D. で記し, 統計学的検定は paired-T test 及び Wilcoxon's rank sum test を用い た. 


\section{結 果}

治療中の平均出力は $43.9 \pm 4.1 \mathrm{Watt}$ で, ラジオメー

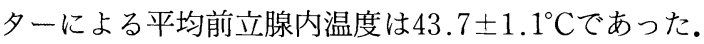
最大前立腺部尿道内圧は治療 2 力月目で $64.1 \pm 17.1$ $\mathrm{cmH}_{2} \mathrm{O}$ から $51.7 \pm 15.6 \mathrm{cmH}_{2} \mathrm{O}$ へと有意に減少した $(\mathrm{p}<0.05)$.

Table 4 に35例の前立腺肥大症患者に対する本療法 の効果を示す，スコア減少率が $25 \%$ 以上のものを有効 とすると, 治療後 2 力月, 6 力月, 1 年目で各々 $71.4 \%$, $71.4 \% ， 48.6 \%$ の有効性を認めた。この間に，自覚症 状の悪化のため, 9 例が前立腺肥大症治療薬および排
尿障害治療薬の併用をうけた.

薬物療法の併用を受けなかった26例の各パラメー ターの経時的変化を Table 5 に示す. 治療後 1 年目で 自覚症状スコア，他覚所見スコア，全スコアとも治療 前に比し有意に改善が認められた $(\mathrm{p}<0.001)$. 但し, 平均尿流率, 最大尿流率は 6 力月後よりやや減少する 傾向があり，残尿量は 1 年後の時点でやや増加してい た.

治療後 1 年目でスコア減少率が $25 \%$ 以上の 17 例につ いて検討すると，その変化（治療前 $\rightarrow$ 治療 2 力月後 $\rightarrow$ 治療 6 力月後 $\rightarrow 1$ 年後) は, 自覚症状スコアは (9.3土

Table 4 Outcome of 35 patients treated with Prostcare

\begin{tabular}{c|c|c|c}
\hline Outcome & $\begin{array}{c}2 \text { months } \\
(\mathrm{n}=35)\end{array}$ & $\begin{array}{c}6 \text { months } \\
(\mathrm{n}==4)\end{array}$ & $\begin{array}{c}1 \text { year } \\
(\mathrm{n}=26)\end{array}$ \\
\hline Reduction rate $\geqq 25 \%$ & $25(71.4 \%) *$ & $25(71.4 \%)$ & $17(48.6 \%)$ \\
remarkable & 16 & 15 & 12 \\
good & 9 & 10 & 5 \\
Reduction rate $<25 \%$ & $10(28.6 \%)$ & $9(25.7 \%)$ & $9(25.7 \%)$ \\
minor & 9 & 7 & 9 \\
none & 1 & 2 & 0 \\
\hline With medical therapies & 0 & 1 & 9 \\
\hline
\end{tabular}

Table 5 Sequential changes in results without medical therapies

\begin{tabular}{l|c|c|c|c}
\hline & Before & 2 months & 6 months & 1 year \\
\hline Subjective score & $9.3 \pm 3.7$ & $4.7 \pm 3.2$ & $4.0 \pm 2.9$ & $4.9 \pm 3.6$ \\
Residual urine $(\mathrm{ml})$ & $100.1 \pm 90.7$ & $22.7 \pm 45.1$ & $19.4 \pm 43.4$ & $35.4 \pm 72.3$ \\
Peak flow rate $(\mathrm{ml} / \mathrm{s})$ & $8.7 \pm 3.2$ & $12.7 \pm 5.3$ & $11.1 \pm 3.2$ & $10.8 \pm 3.7$ \\
Average flow rate(ml/s) & $4.1 \pm 1.9$ & $6.5 \pm 2.6$ & $5.9 \pm 2.2$ & $5.5 \pm 2.1$ \\
Objective score & $9.2 \pm 2.8$ & $5.1 \pm 2.8$ & $5.5 \pm 2.6$ & $5.5 \pm 2.7$ \\
Total score & $18.5 \pm 5.8$ & $9.7 \pm 5.4$ & $9.6 \pm 4.7$ & $10.8 \pm 5.8$ \\
\hline
\end{tabular}

All value showed significant $(\mathrm{p}<0.001)$ improvement compared with pretreatment levels during the period.

Table 6 Characteristics of effective group and non-effective group

\begin{tabular}{l|c|c|c}
\hline & $\begin{array}{c}\text { Effective group } \\
(\mathrm{n}=17)\end{array}$ & $\begin{array}{c}\text { Non-effective group } \\
(\mathrm{n}=18)\end{array}$ & $\begin{array}{c}\text { Statistical } \\
\text { analysis }\end{array}$ \\
\hline Age & $68.4 \pm 9.4$ & $72.4 \pm 8.1$ & N.S. \\
Prostate volume $(\mathrm{ml})$ & $35.3 \pm 18.1$ & $33.9 \pm 14.4$ & N.S. \\
Maximum power output $(\mathrm{Watt})$ & $43.2 \pm 4.7$ & $44.7 \pm 3.6$ & N.S. \\
Intraprostatic temperature $\left({ }^{\circ} \mathrm{C}\right)$ & $44.2 \pm 1.2$ & $43.3 \pm 0.8$ & $\mathrm{p}<0.05$ \\
Subective score & $9.3 \pm 3.5$ & $10.0 \pm 3.6$ & N.S. \\
Residual urine $(\mathrm{ml})$ & $86.3 \pm 66.2$ & $156.6 \pm 137.2$ & N.S. \\
Average flow rate $(\mathrm{ml} / \mathrm{s})$ & $4.4 \pm 1.9$ & $3.5 \pm 1.5$ & N.S. \\
Peak flow rate $(\mathrm{ml} / \mathrm{s})$ & $8.9 \pm 3.3$ & $7.8 \pm 2.8$ & N.S. \\
\hline
\end{tabular}

Effective group is reduction rate $\geqq 25 \%$ and non-effective group is reduction rate $<25 \%$. N.S. : not significant. 
$3.5 \rightarrow 4.5 \pm 3.3 \rightarrow 3.4 \pm 3.0 \rightarrow 3.7 \pm 2.9)$ と，他覚所見ス コアは $(8.9 \pm 2.4 \rightarrow 4.5 \pm 2.4 \rightarrow 4.6 \pm 1.8 \rightarrow 4.4 \pm 1.5)$

と, 両者の変化はほぼ一致した。

治療後 1 年目において TUMT が有効であった群 （スコア減少率 $25 \%$ 以上）と無効であった群（スコア減 少率 $25 \%$ 未満) の背景因子を Table 6 に示す.ラジオ メトリー法による平均前立腺内温度は有効群で有意に 高かったが $(\mathrm{p}<0.05)$, 前立腺体積, 自覚症状スコア, 残尿量, 平均尿流率, 最大尿流率などには有意差はな かった.

最大前立腺部尿道内圧は, 有効群では治療前および 治療 2 力月後で $64.9 \pm 16.7 \mathrm{cmH}_{2} \mathrm{O}$ から $50.5 \pm 12.6$ $\mathrm{cmH}_{2} \mathrm{O}$ と有意に減少 $(\mathrm{p}<0.01)$ したが，無効群では $57.1 \pm 12.2 \mathrm{cmH}_{2} \mathrm{O}$ から $54.6 \pm 14.4 \mathrm{cmH}_{2} \mathrm{O}$ と有意差 を認めなかった。

前立腺の組織型による治療 1 年目のスコア減少率の 比較では stromal hyperplasia ( $\mathrm{n}=8)$ は $32.9 \pm 27.8 \%$, glandular hyperplasia $(n=5)$ は $34.1 \pm 36.3 \%$, mixed type $(n=7)$ は $30.7 \pm 23.5 \%$ と各組織型による有意差 は認められなかった。

副作用

治療中の副作用では25例（80.6\%）に灼熱感が見ら れたが治療終了とともに消失した。10例（32.2\%）で 強い尿意のためカテーテル周囲よりの排尿が認められ たが特別な処置を要さなかった。肉眼的血尿は治療後 より 27 例 $(87.1 \%)$ に見られたが全例 1 週間以内に消 失した。.また尿路感染症, 尿閉, 尿失禁は 1 例も認め ず，その他の重篤な合併症は認めなかった。

治療前後で行った検尿, 血算, 血液生化学検査, 前 立腺腫瘍マーカーでは特に有意な変化は認めなかっ た。

患者の満足度

薬物療法の併用を受けなかった 26 例について治療 1 年後における排尿状態に対するアンケート調查（満足 度）を施行した。結果は『満足』が 5 例 (19.2\%),『や や満足』が12例 $(46.2 \%)$,『どちらともいえない』が 5 例 $(19.2 \%)$, 『やや不満足』が 3 例 $(11.5 \%)$ ，『不 満足』が 1 例 $(3.9 \%)$ で $65.4 \%$ にやや満足以上の満足 度が得られた。

\section{考 察}

前立腺肥大症に対する治療法は経尿道的切除術や薬 物療法が用いられてきたが，バルーン拡張術や尿道ス テント留置術, 最近になって温熱療法が注目されるよ うになった。
温熱療法は抗腫瘍効果を得る目的で悪性腫瘍の治療 に用いられてきた。前立腺癌の温熱療法は1980年 Mendecki ら ${ }^{1)}$ にりはじめて腫瘍の縮小効果が報告 され, 平井ら ${ }^{2)}$ 尿路閉塞症状の改善に有効であると 報告している，本格的な前立腺肥大症による排尿障害

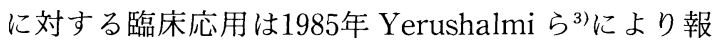
告された。

今回，フランス BRUKER 社製プロストケアを用い て, 前立腺肥大症による排尿障害を有した35例の患者 を治療する機会を得たのでその結果を報告した。 全ス コア減少率は治療後 2 力月で 25 例 $(71.4 \%)$ 亿有効性 を認めたが 1 年目には 17 例 (48.6\%) と減少した。有 効群では前立腺内温度が無効群に比し有意に上昇して いたことより，プロストケアの出力を上げ前立腺内温 度をさらに上昇させることで治療効果を高めることが できるかもしれない. また有効群では前立腺部尿道内 圧が治療後, 有意に低下することが認められた。 Perachino ら" はプロスタトロン（Technomed 社製）を用 いた TUMT 後 3 日目に open prostatectomy を施行 した10例の前立腺組織を免疫組織化学染色したとこ ろ, 尿道粘膜から $0.5 \sim 2.0 \mathrm{~cm}$ 深さの部位で神経線維 の消失および損傷が認められたとしている. マイクロ 波により前立腺内温度が上昇することで $\alpha_{1}$-receptor が破壊され前立腺の平滑筋線維の収縮能が低下し, 前 立腺部尿道の内圧が減少し， $\alpha_{1}$ ブロッカー製剤と同様 の作用がある可能性が示唆された。最近では TUMT により組織が熱性変性に陥り縮小する所見も報告され ている.

治療中の副作用は血尿, 尿意切迫感, 灼熱感を認め たが，いずれも一過性で特別な処置を要したものはな かった.

プロストケアの特徵はラジオメトリー法を利用して いることである。アンテナはマイクロ波を発信する装 置であると同時に温度を測定する装置である。このた め前立腺内の温度を非侵襲的に測定でき, 直腸内に温 度測定用プローブを挿入しないですむのが大きな特徵 である。またアンテナ周囲の熱分布が棈円形を呈して いるため，尿道外括約筋領域の温度はあまり上昇しな いようになっており，今回の治療で尿失禁を認めた患 者はいなかった。

プロストケアによる同様な治療方法を用いた Belot $ら^{5)}$ の報告によると, 効果判定を 3 力月後と 6 力月後 行った結果, Madsenによる自覚症状スコアは11.2か ら $2.5,3.1$ へと減少し, 最大尿流率は $9.6 \mathrm{ml} / \mathrm{s}$ から 12.3 
$\mathrm{ml} / \mathrm{s}, 12.5 \mathrm{ml} / \mathrm{s}$ へと改善し, 残尿量は $102 \mathrm{ml}$ から 68 $\mathrm{ml}, 53 \mathrm{ml}$ へと減少したとしている.この報告と比べ, 本検討では残尿量の改善が若干良好であるが, Belot らの症例では前立腺容積が平均 $39.7 \mathrm{ml}$ で本検討では 平均 $34.6 \mathrm{ml}$ と背景因子にやや差があるためと考えら れた。

Ogden $ら^{6)}$ は, 前立腺肥大症に対する経尿道的マイ クロ波温熱療法の効果について検討した結果, 3 カ月 後の効果判定では温熱療法群は Madsen による自覚 症状スコアは70\%の低下が認められ, 最大尿流率は8.5 $\mathrm{ml} / \mathrm{sec}$ から $13.0 \mathrm{ml} / \mathrm{sec}$ と増加し, 残尿量は $147 \mathrm{ml}$ か ら $12 \mathrm{ml}$ に減少した。一方, 非加温対象群ではいずれに ついても有意な改善はなく, プラセボ効果は認められ ず，経尿道的マイクロ波温熱療法の有効性は明らか だったとしている。

一方, Dahlstrand ら ${ }^{7)}$ は TUMT と経尿道的前立腺 切除術 (以下 TURP) の効果を比較した結果, 1 年後 の効果判定では, Madsenの自覚症状スコアは TUMT 群で76\%の低下，TURP 群は93\%の低下が認 められ, 最大尿流率はTUMT 群で $8.0 \mathrm{ml} / \mathrm{sec}$ から $12.3 \mathrm{ml} / \mathrm{sec}$, TURP群 $て ゙ 7.9 \mathrm{ml} / \mathrm{sec}$ か $17.7 \mathrm{ml} /$ secへの改善が得られ, 特に他覚所見において, TURP 群でより優れた臨床効果が認められたとしている。し かし, 合併症は TURP 群により多く認められ, 自覚症 状スコアの改善率も両者間で近接していることより, TUMT の低侵襲性の利点を強調している.

近年，レーザーを応用したより侵襲の少ない外科的 治療が注目されつつある ${ }^{8)}$.このような状況の中, 今後 どのように温熱療法を利用していくかが問題であろ う.

温熱療法は薬物療法と外科療法の中間に位置すると 考えられる. 本法はなんらかの合併症のため外科療法 が不可能な患者，あるいは性的機能を保持したいと望 んでいる患者が良い適応であると考えられた。

本治療法（単回 1 時間）は 1 年後の効果判定に扔い ても49\%の有効性を認めたが，この効果がいつまで持 続するかさらに長期の経過観察が必要である.

\section{結語}

プロストケアによる経尿道的高温度療法を用い前立 腺肥大症に対し単回の外来治療で治療後 2 力月, 6 力 月および 1 年後に効果判定を行った。

治療後 1 年目で自覚症状及び他覚所見の両者のスコ アの合計值は, $18.5 \pm 5.8$ から $10.8 \pm 5.8$ と統計学的に
有意に減少した $(\mathrm{p}<0.001)$. スコア合計值の減少率が $25 \%$ 以上ものを有効とすると，17例 $(48.6 \%)$ の有 効性を認めた。

有効群では前立腺内温度は有意に上昇し, 前立腺部 尿道内圧は治療後に有意に低下していた。

治療前の生検で得られた前立腺の組織型により治療 効果に有意差を認めなかった。

副作用は, 特に重篤な合併症は認めなかった.

\section{文献}

1) Mendecki, J., Friedenthal, E., Botstein, C., Paglione, R. and Sterzer, F.: Microwave applicators for localized hyperthermia treatment of cancer of the prostate. Int. J. Rad. Oncol. Biol. Phys., 6, 1583-1588, 1989.

2）平井正孝, 中野 優, 牛山知已, 増田宏昭, 太田信 隆, 田島 嵉, 河邊香月, 阿曾佳郎：前立腺癌に対 する温熱療法の試み. 日泌尿会誌, 79, 1761-1764, 1988.

3) Yershalmi, A., Fishelovitz, Y., Singer, D., Reiner, I., Arielly, J., Abramovici, Y., Catsenelson, R., Levy, E. and Shani, A.: Localized deep microwave hyperthermia in treatment of poor operative risk patients with benign prostatic hyperplasia.J. Urol., 133, 873-876, 1985.

4) Perachino, M., Bozzo, W., Puppo, P., Vitali, A., Ardoino, S. and Ferro, M.A. : Dose transurethral thermotherapy induce a long-term alpha blockade? Eur. Urol., 23, 299-301, 1993.

5) Belot, G. and Chive, M.: Transurethral thermotherapy of the benign prostate hypertrophy controlled by radiometry. Eur. Urol., 23, 326-329, 1993.

6) Ogden, C.W., Peddy, P., Johnson, H., Ramsay, J. W.A. and Carter, S.ST.C.: Sham versus transurethral microwave thermotherapy in patients with symptoms of benign prostatic bladder outflow obstraction. Lancet, 341, 14-17, 1993.

7) Dahlstrand, C., Geirsson, G., Fall, M. and Petterson, S.: Transurethral microwave thermotherapy versus transurethral resection for benign prostatic hyperplasia : Preliminary results of a randomized study. Eur. Urol., 23, 292-298, 1993.

8) Norris, J.P., Norris, D.M., Lee, R.D. and Rubenstein, M.A.: Visual laser ablation of the prostate: Clinical experience in 108 patients. J. Urol., 150, 1612-1614, 1993. (1994年4月25日受付，8月22日受理） 